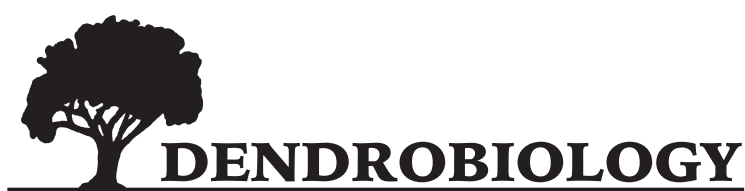

2013, vol. 69, 111-115

Mustafa Yilmaz, Fatih Tonguç*

\section{Effects of temperature on the germination of Fraxinus ornus subsp. cilicica seeds}

Received: 12 March 2012; Accepted 3 June 2012

\begin{abstract}
The present study was carried out to determine the effect of temperature on the seed germination of Fraxinus ornus subsp. cilicica, an endemic taxa on Taurus Mountains in Southern Turkey. Seeds from the three provenances were collected and prechilled for 16 weeks before the germination tests. Germination tests were conducted at constant temperatures $\left(5,15,20,25^{\circ} \mathrm{C}\right)$ and at alternating temperatures $(5 \sim 15,5 \sim 20,5 \sim 25$, $15 \sim 25^{\circ} \mathrm{C}$ ). Temperature treatments were effective on germination percentage and mean germination time. The highest and the lowest germinability were obtained at the $5-15^{\circ} \mathrm{C}(73.3 \%)$ alternating and $25^{\circ} \mathrm{C}(9.8 \%)$ constant temperatures, respectively. Mean germination time greatly differed at various temperature regimes. Germination accelerated with increased constant temperatures while it was relatively similar speed at alternating temperatures used in the tests. Seed sources had also an effect on the final germination percentage.
\end{abstract}

Additional key words: Dormancy, seed germination, Taurus flowering ash

Address: M. Yilmaz, F. Tonguç* Kahramanmaraş Sütçü Imam University, Faculty of Forestry, Department of Silviculture, Kahramanmaraæ 46100 Turkey, e-mail: ftonguc@ksu.edu.tr

*Corresponding author

\section{Introduction}

Fraxinus ornus subsp. cilicica (Lingelsh) Yalt., Taurus flowering ash, is an endemic tree dispersed over Taurus Mountains in Southern Turkey. Its height is usually around $8-10 \mathrm{~m}$ and can reach up to $20 \mathrm{~m}$ height (Yaltirik 1978; Browicz 1984; Yilmaz and Tonguc 2009). The tree prefers sunny southern slopes in karstic areas and grows from $350 \mathrm{~m}$ to $1500 \mathrm{~m}$ above sea level. It has ornamental value due to its flowers, foliage, and interesting crown form (Dirr and Heuser 1987).

Fraxinus ornus (Oleaceae), also known Manna ash (Fraxigen 2005), is an insect-pollinated tree (Verdú et al. 2006). F. ornus fruits are elongated, winged, single-seeded samaras that are borne in panicles (Bonner 2002). The species has male and hermaphrodite trees in breeding population (androdioecy) and only hermaphrodite trees bear fruits (Dommee et al. 1999; Verdú 2004; Verdú et al. 2007).

Throughout its natural distribution, F. ornus subsp. cilicica wood is used to make shovel handles and therefore scattered populations of this species are under the threat of illegal harvest. There are no special conservation programs for this ornamental endemic tree species, which can be used for many purposes such as urban landscape design and manna production. In recent decades, there is an increasing interest in using native local trees for reforestation and urban plantings (Ürgenç 1998; Grey and Deneke 1992). Detailed studies on the seed physiology of this endemic species are needed before widespread seedling production of F. ornus subsp. cilicica can be successfully carried out.

Temperature is one of the most effective factors on the germination behavior of seeds (Bewley and Black 
1994; Schmidt 2000). The temperature requirements for seed germination vary by species, variety, and sometimes, populations used for seed sources. Ideal temperature range for germination is also related to the ecology of the species location (Baskin and Baskin 1998; Fenner and Thompson 2005).

The main objective of this study was to determine the effect of different temperature regimes on the germinability and germination speed of $F$. ornus subsp. cilicica seeds collected from three provenances.

\section{Materials and Methods}

\section{Seed Material}

The samaras were collected from three provenances in Turkey (Table 1) at the first week of November 2007. In the laboratory, samaras were air-dried until they reached about $8 \%$ moisture content (MC). MC of seeds was determined by low temperature oven method (ISTA 1996). MC was calculated as the percentage of the fresh weight of the seed.

\section{Germination Temperature}

F. ornus subsp. cilicica seeds have deep physiological dormancy and need about $16-18 \mathrm{w}$ prechilling before the germination test (Yilmaz and Tonguc 2008). To find out the effect of temperature on the germination response, seeds from 3 different provenances (Andirin, Kozan, Pozanti) were prechilled without media for 16 weeks in a fridge $\left(3^{\circ} \mathrm{C}\right)$. Prechilling was applied in the plastic bottles covered with perforated aluminum folio under dark conditions. To keep the level of seed moisture content between $40-42 \%$ MC, distilled water was sprayed on the seeds once in every two week period throughout the study. MC of the seeds during the prechilling treatments without media should generally be close to $8-10$ point below the maximum MC of the seeds (Yilmaz 2006), therefore MC of seeds were kept 8-10 point (about $40-42 \%$ ) below the maximum MC of the seeds (50.5\%) during prechilling period.

Seeds were subjected to germination test at eight different temperature regimes after the prechilling treatments. Germination tests were performed at constant temperatures $\left(5,15,20,25^{\circ} \mathrm{C}\right)$ and at alternating temperatures $\left(5 \sim 15,5 \sim 20,5 \sim 25,15 \sim 25^{\circ} \mathrm{C}\right)$. During the germination tests seeds were kept at dark for $16 \mathrm{~h}$ and under light for $8 \mathrm{~h}$. Germination tests were carried out on two layers of filter paper in $15 \mathrm{~cm}$ Petri dishes. Filter papers were changed if there was fungal development. Three replications of 50 seeds were used in the germination tests. Seeds were rinsed with sterile distilled water for one minute to remove dust from the seed surface prior to the germination tests. Seeds were considered germinated when their radicles protruded $3 \mathrm{~mm}$ and showed geotropism. The petri dishes were checked every two days and the germinated seeds were counted and removed. Germination tests were terminated after 28 days.

\section{Germination Parameters}

In the germination tests, germination percentage (GP) and mean germination time (MGT) were calculated according to the following formulas (Bewley and Black 1994):

$$
G P \%=\frac{\sum n_{i}}{N} \times 100
$$

Where GP (\%) is the germination percentage, $n_{i}$ is the number of germinated seeds at day $\mathrm{i}$, and $\mathrm{N}$ is the total number of incubated seeds per test.

$$
M G T=\frac{\sum\left(t_{i} \cdot n_{i}\right)}{\sum n_{i}}
$$

Where MGT is the mean germination time, $t_{i}$ is the number of days from the beginning of the test, and $n_{i}$ is the number of germinated seeds recorded on day $t_{(i)}$.

\section{Statistical Analyses}

GP and MGT values of treatments were subjected to factorial ANOVA to detect the significance of germination temperatures and provenances. GP values was transformed using arcsine formula to normalize error distribution prior to variance analyses. When a significant effect was detected, differences among the groups were identified using Duncan's New Multiple Range test.

\section{Results}

Both germination temperature and provenance had significant effect on the germination percentage. Temperature $\times$ provenance interaction for GP $(P<0.01)$ was also significant (Table 2). GPs varied

\begin{tabular}{|c|c|c|c|c|c|c|}
\hline Provenance & Latitude & Longitude & Elevation (m) & 1000-seed weight* $(\mathrm{g})$ & Samara Length (mm) & Seed Length (mm) \\
\hline Andirin/K.Maraş & $37^{\circ} 36^{\prime}$ & $36^{\circ} 24^{\prime}$ & 1150 & 26.1 & 23.13 & 9.00 \\
\hline Kozan/Adana & $37^{\circ} 31^{\prime}$ & $35^{\circ} 52^{\prime}$ & 380 & 27.0 & 21.13 & 8.49 \\
\hline Pozanti/Adana & $37^{\circ} 22^{\prime}$ & $34^{\circ} 53^{\prime}$ & 1150 & 32.6 & 25.01 & 8.67 \\
\hline
\end{tabular}

Table 1. Information on seeds used in the study (Yilmaz and Tonguc 2008)

*Air dry weight at $8 \%$ moisture content. 
Table 2. Temperature and seed provenance effect on germination percentage (GP) and mean germination time (MGT)

\begin{tabular}{lrrrrrrr}
\hline \multirow{2}{*}{ Source } & df & \multicolumn{3}{c}{ GP } & \multicolumn{3}{c}{ MGT } \\
\cline { 3 - 8 } & & \multicolumn{1}{c}{ MS } & F & P-value & MS & F & P-value \\
\hline Temperature (T) & 7 & 1795 & 256.7 & 0.000 & 74.12 & 213.81 & 0.000 \\
Provenance (P) & 2 & 1391 & 198.9 & 0.000 & 0.44 & 1.27 & 0.290 \\
$\mathrm{~T} \times \mathrm{P}$ & 14 & 59 & 8.5 & 0.000 & 0.80 & 2.30 & 0.017 \\
Error & 48 & 7 & & & 0.35 & & \\
\hline
\end{tabular}

depending on the temperature treatments and were the highest at the $5 \sim 15^{\circ} \mathrm{C}$ alternating and $5^{\circ} \mathrm{C}$ constant temperature (Fig. 1). GPs were also relatively high at $5 \sim 20^{\circ} \mathrm{C}$ and $15 \sim 25^{\circ} \mathrm{C}$ alternating temperatures. GPs decreased at constant temperatures as temperature increased. Although GPs were similar at $12^{\circ} \mathrm{C}, 15^{\circ} \mathrm{C}$, and $18^{\circ} \mathrm{C}$, there were significant differences between $18^{\circ} \mathrm{C}$ and $21^{\circ} \mathrm{C}$ and between $21^{\circ} \mathrm{C}$ and $24^{\circ} \mathrm{C}$. In another words, GPs began to decrease between $18^{\circ} \mathrm{C}$ and $21^{\circ} \mathrm{C}$. The lowest GP $(9.8 \%)$ value was found at $25^{\circ} \mathrm{C}$ constant temperature. There were significant differences between provenances for GP as well. Seeds collected from Andirin provenance demonstrated the highest germinability while Kozan and Pozanti provenance exhibited similar germination percentages.

MGT distinctly differed at various temperature regimes. Germination accelerated with an increase in constant temperature (Table 4). Germination was fastest at $25^{\circ} \mathrm{C}$ and while at the same temperature the lowest GP was obtained. There was no statistically important differences for MGT between provenances.
However, interaction between provenance and germination temperature was statistically important for MGT $(\mathrm{P}<0.05)$.

\section{Discussion}

Present study revealed the strong effect of temperature on the germination of

F. ornus subsp. cilicica seeds (Table 3,4 ). Among the tested temperature regimes, $5 \sim 15^{\circ} \mathrm{C}$ alternating temperature and $5^{\circ} \mathrm{C}$ constant temperature appeared to be suitable germinating temperatures since germination percentages were significantly lower at any other temperature regimes tested during the study. In the current study, alternating temperature regimes generally provoked the germination and gave higher GPs than those of the constant temperatures (Table 3). It is also observed that the seeds from different populations differ from each other for germinating ability as Andirin population's GP value was higher than those of Pozanti and Kozan populations.

Table 3. Germination percentage ${ }^{1}$ of seeds at different temperature regimes treatment

\begin{tabular}{lccccccccc}
\hline \multirow{2}{*}{ Provenance } & \multicolumn{7}{c}{ Germination percentage (\%) } & & \\
\cline { 2 - 7 } & $5{ }^{\circ} \mathrm{C}$ & $15^{\circ} \mathrm{C}$ & $20^{\circ} \mathrm{C}$ & $25^{\circ} \mathrm{C}$ & $5 \sim 15^{\circ} \mathrm{C}$ & $5 \sim 20^{\circ} \mathrm{C}$ & $5 \sim 25^{\circ} \mathrm{C}$ & $15 \sim 25^{\circ} \mathrm{C}$ & \\
\hline Kozan & $64.7 \mathrm{a}$ & $50.0 \mathrm{C}$ & $38.0 \mathrm{~d}$ & $12.0 \mathrm{e}$ & $68.7 \mathrm{a}$ & $57.3 \mathrm{~b}$ & $40.0 \mathrm{~d}$ & $55.3 \mathrm{bc}$ & $48.3 \mathrm{~B}$ \\
Andirin & $89.3 \mathrm{a}$ & $61.3 \mathrm{~d}$ & $35.3 \mathrm{e}$ & $10.7 \mathrm{f}$ & $91.3 \mathrm{a}$ & $81.3 \mathrm{~b}$ & $70.7 \mathrm{c}$ & $79.3 \mathrm{~b}$ & $64.8 \mathrm{~A}$ \\
Pozanti & $61.3 \mathrm{a}$ & $37.3 \mathrm{~b}$ & $22.0 \mathrm{c}$ & $6.7 \mathrm{~d}$ & $60.0 \mathrm{a}$ & $55.3 \mathrm{a}$ & $42.0 \mathrm{~b}$ & $54.0 \mathrm{a}$ & $42.3 \mathrm{~B}$ \\
Average & $71.8 \mathrm{a}$ & $49.5 \mathrm{C}$ & $31.8 \mathrm{~d}$ & $9.8 \mathrm{e}$ & $73.3 \mathrm{a}$ & $64.6 \mathrm{~b}$ & $50.9 \mathrm{c}$ & $62.9 \mathrm{~b}$ & \\
\hline
\end{tabular}

${ }^{1}$ The values on the same line followed by the same letters are not significantly different at $\mathrm{P}<0.05$.

${ }^{2}$ The values on the same column followed by the same capital letters are not significantly different at $\mathrm{P}<0.01$.

Table 4. Mean germination time ${ }^{1}$ of seeds at different temperatures treatment

\begin{tabular}{lccccccccc}
\hline \multirow{2}{*}{ Provenance } & \multicolumn{7}{c}{ Mean germination time (days) } \\
\cline { 2 - 7 } & $5^{\circ} \mathrm{C}$ & $15^{\circ} \mathrm{C}$ & $20^{\circ} \mathrm{C}$ & $25^{\circ} \mathrm{C}$ & $5 \sim 15^{\circ} \mathrm{C}$ & $5 \sim 20^{\circ} \mathrm{C}$ & $5 \sim 25^{\circ} \mathrm{C}$ & $15 \sim 25^{\circ} \mathrm{C}$ & Average $^{2}$ \\
\hline Kozan & $14.7 \mathrm{e}$ & $10.2 \mathrm{bc}$ & $9.3 \mathrm{~b}$ & $6.1 \mathrm{a}$ & $12.0 \mathrm{~d}$ & $11.1 \mathrm{~cd}$ & $10.3 \mathrm{bc}$ & $12.5 \mathrm{~d}$ & $10.8 \mathrm{~A}$ \\
Andirin & $14.8 \mathrm{e}$ & $11.0 \mathrm{c}$ & $9.1 \mathrm{~b}$ & $4.7 \mathrm{a}$ & $12.5 \mathrm{c}$ & $11.5 \mathrm{c}$ & $10.8 \mathrm{c}$ & $13.0 \mathrm{~d}$ & $10.9 \mathrm{~A}$ \\
Pozanti & $14.6 \mathrm{e}$ & $10.4 \mathrm{c}$ & $8.9 \mathrm{~b}$ & $4.5 \mathrm{a}$ & $13.1 \mathrm{~d}$ & $10.2 \mathrm{bc}$ & $10.9 \mathrm{c}$ & $12.8 \mathrm{~d}$ & $10.7 \mathrm{~A}$ \\
Average & $14.7 \mathrm{e}$ & $10.5 \mathrm{C}$ & $9.1 \mathrm{~b}$ & $5.1 \mathrm{a}$ & $12.5 \mathrm{~d}$ & $10.9 \mathrm{c}$ & $10.7 \mathrm{c}$ & $12.8 \mathrm{~d}$ & \\
\hline
\end{tabular}

${ }^{1}$ The values on the same line followed by the same small letters are not significantly different at $\mathrm{P}<0.01$.

${ }^{2}$ The average values on the same column followed by the same capital letters are not significantly different at $\mathrm{P}<0.01$. 


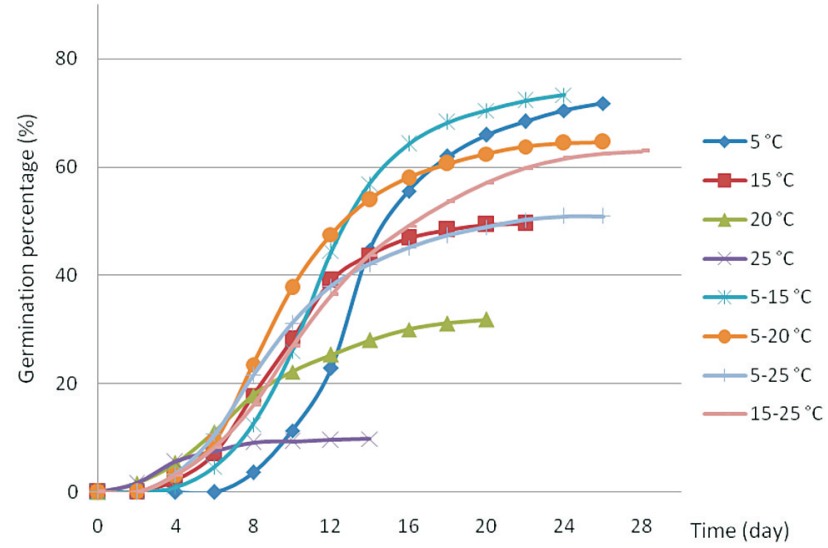

Fig. 1. Average germination percentage of three provenances at different temperature regimes

Germination temperature is very effective on the germination parameters. Different germination temperatures such as $20 \sim 30^{\circ} \mathrm{C}, 5 \sim 15^{\circ} \mathrm{C}, 3 \sim 20^{\circ} \mathrm{C}$, $3 \sim 25^{\circ} \mathrm{C}$ and $20^{\circ} \mathrm{C}$, have been used in the germination of pretreated Fraxinus spp. seeds (Steinbauer 1937; Tylkowski 1988 and 1990, ISTA 1996; Suszka et al. 1996; Tilki and Çiçek 2005; Draghici and Abrudan 2011). ISTA (1996) suggests the alternating temperature of $20 \sim 30^{\circ} \mathrm{C}$ for the seeds of Fraxinus spp. seeds. On the other hand, alternating temperature of $5 \sim 25^{\circ} \mathrm{C}$ provides better germination performance for F. ornus (Piotto 1994) and F. angustifolia (Piotto 1997; Piotto and Piccini 1998) seeds. In the current study, the alternating temperature of $5 \sim 15^{\circ} \mathrm{C}$ resulted in higher germination percentage. Similarly, F. excelsior seeds had higher germination at alternating temperature of $5 \sim 15^{\circ} \mathrm{C}$ (Suszka et al. 1996).

Germination percentages generally decreased at $20^{\circ} \mathrm{C}$ or higher constant or alternating temperatures (Table 3). Germination temperatures higher than the optimum temperature usually cause secondary dormancy (Khan and Samimy 1982; Copeland and McDonald 1999). Lower germinability observed at $20^{\circ} \mathrm{C}$ or higher temperatures might be the result of secondary dormancy. Tylkowski (1988) and Piotto and Di Noi (2003) reported secondary dormancy phenomenon observed in Fraxinus spp. seeds at $20^{\circ} \mathrm{C}$. Similar behavior of secondary dormancy over $20^{\circ} \mathrm{C}$ was reported for the beechnuts as well (Gugała 2002; Yilmaz 2005).

In the current study, although the germination percentage was relatively high at the constant temperature of $15^{\circ} \mathrm{C}$, germinability declined rapidly at $20^{\circ} \mathrm{C}$ and $25^{\circ} \mathrm{C}$ constant temperatures (Table 4). Similarly, the germination of $F$. angustifolia at $20^{\circ} \mathrm{C}$ constant temperature was significantly lower than those at $4 \sim 20^{\circ} \mathrm{C}$ and $20 \sim 30^{\circ} \mathrm{C}$ alternating temperatures (Tilki and Çiçek 2005). The overall results indicate that $F$. ornus ssp. cilicica seeds exhibit better germination performance at alternating temperatures and at lower constant temperatures, which is somewhat different than seed germination behavior of many woody species.

For successful growth of plants, seedling development is important. Plants need photosynthesis for development after germination and alternating temperature and light. Therefore germination conditions at alternating temperatures such as $5 \sim 15^{\circ} \mathrm{C}$ and $3 \sim 20^{\circ} \mathrm{C}$ are accepted more realistic due to similarity to the germination temperatures in nature and nurseries (Falleri et al. 2004). The lower temperatures of alternating temperatures such as $5^{\circ} \mathrm{C}$ are effective in removing the dormancy of still dormant seeds after the prechilling treatment. Therefore, when the prechilling duration is insufficient, higher germination percentages are obtained alternating temperatures. Alternating temperatures also stimulate seed germination of many species (Bradbeer 1988; Bewley and Black 1994). In fact, the germination percentage of $15 \sim 25^{\circ} \mathrm{C}$ alternating temperature was much higher than those of $15^{\circ} \mathrm{C}$ and $25^{\circ} \mathrm{C}$ constant temperature in the current study (Table 3 ). The prechilling duration for the germination tests at alternating temperatures can be short for those at constant temperatures (Yilmaz 2005). Therefore, 16 weeks prechilling duration for $F$. ornus ssp. cilicica seeds could be extended for few weeks if the germination tests are applied at constant temperatures.

Genetic diversity among and within populations are very common in woody species. Topography and climate conditions also affect diversity (Kaya and Raynal 2001; Çalişkan 2006). Further research is needed on the seed, seedling and other characteristics of this endemic species.

\section{Acknowledgment}

This study was supported by The Scientific and Technological Research Council of Turkey (TUBÝTAK) under project number 107 O 624.

\section{References}

Baskin C.C., Baskin J.M. 1998. Seeds. Ecology, biogeography, and evolution of dormancy and germination. Academic Press, San Diego.

Bewley J.D., Black M. 1994. Seeds: Physiology of Development and Germination. Plenum Press, New York.

Bradbeer J.W. 1988. Seed Dormancy and Germination. Blackie and Son Limited, London.

Bonner F.T. 2002. Fraxinus. In: Woody plants seed manual. Bonner F.T., Nisley R.G. (eds.) USDA Forest Service, pp. 416-420.

Browicz K. 1984. Chorology of trees and shrubs in south-west asia and adjacent regions. Polish Academy of Sciences, Institute of Dendrology, Polish Scientific Publishers, Poznan. 3: 20-21. 
Copeland L.O., McDonald M.B. 1999. Seed Science and Technology. Kluwer Academic Publishers, Boston.

Çalişkan S. 2006. Genetic diversity among and within the populations of natural Turkish redpine (Pinus brutia Ten.). Ýstanbul University. Journal of Faculty of Forestry Serial A, 56: 169-196.

Dirr M.A., Heuser C.W. 1987. The Reference Manual of Woody Plant Propagation. Varsity Press, Athens, GA, USA.

Dommée B., Geslot A., Thompson J.D., Reille M., Denelle N. 1999. Androdioecy in the entomophilous tree Fraxinus ornus (Oleaceae). New Phytologist 143: 419-426.

Drãghici C., Abrudan, I.V., 2011. The effect of different stratification conditions on the germination of Fraxinus angustifolia Vahl. and F. ornus L. seeds. Notulae Botanicae Horti Agrobotanici Cluj-Napoca 39: 283-287.

Falleri E., Muller C., Laroppe E. 2004. Effect of water stress on germination of beechnuts treated before and after storage. Canadian Journal of Forest Research 34: 1204-1209.

Fenner M., Thompson K. 2005. The Ecology of Seeds. Cambridge University Press, UK.

Fraxigen. 2005. Ash species in Europe: Biological characteristics and practical guidelines for sustainable use. Oxford Forestry Institute, University of Oxford, UK.

Grey G.W., Deneke F.J. 1992. Urban Forestry. Krieger Publishing Company, Florida, USA.

Gugała A. 2002. Changes in quality of beech (Fagus sylvatica L.) seeds stored at the Forest Gene Bank Kostrzyca. Dendrobiology 47s: 33-38.

ISTA 1996. International Rules for Seed Testing. Seed Science and Technology 24s: 1-335.

Kaya Z., Raynal D.J. 2001. Biodiversity and conservation of Turkish forests. Biological Conservation 97: 131-141.

Khan A.A., Samimy E.C. 1982. Hormones in relation to primary and secondary seed dormancy. In: Physiology and Biochemistry of Seed Development, Dormancy and Germination. Khan A.A. (ed.). Elsevier, Amsterdam, pp. 203-241.

Piotto B. 1994. Effects of temperature on germination of stratified seeds of three ash species. Seed Science and Technology 22: 519-529.

Piotto B. 1997. Storage of non-dormant seeds of Fraxinus angustifolia (Vahl). New Forests 14: 157-166.

Piotto B., Piccini, C. 1998. Influence of pretreatment and temperature on the germination of Fraxinus angustifolia seeds. Seed Science and Technology 26: 799-812.

Piotto B., Di Noi A. 2003. Seed Propagation of Mediterranean Trees and Shrubs. ANPA, Roma.
Schmidt L. 2000. Guide To Handling of Tropical and Subtropical Forest Seed. Danida Forest Seed Centre, Denmark.

Steinbauer G.P. 1937. Dormancy and germination of Fraxinus seeds. Plant Physiology 1: 813-824.

Suszka B., Muller C., Bonnet-Masimbert M. 1996. Seeds of Forest Broadleaves, From Harvest to Sowing. INRA, France.

Tilki F., Çiçek E. 2005. Effects of stratification, storage and temperature on germination of three provenances of narrow leaved ash (Fraxinus angustifolia subsp. oxycarpa) seeds. Turkish Journal of Agriculture and Forestry 29: 323-330.

Tylkowski T. 1988. Storage of stratified seeds of European ash (Fraxinus excelsior L.). Arboretum Kórnickie 33: 259-266.

Tylkowski T. 1990. Mediumless stratification and dry storage of Fraxinus excelsior L. Arboretum Kórnickie 35: 143-152.

Ürgenç S. 1998. Ağaçlandýrma Tekniği. Ýstanbul Üniversitesi, Orman Fakültesi Yayýnlarý, No: 3994/441, Ýstanbul.

Verdú M., Spanos K., Čaňová I., Slobodník B., Paule L. 2007. Similar gender dimorphism in the costs of production across the geographic range of Fraxinus ornus. Annals of Botany 99: 183-191.

Verdú M. 2004. Physiological and reproductive differences between hermaphrodites and males in the androdioecious plant Fraxinus ornus. Oikos 105: 239-246.

Verdú M., González-Martínez S.V., Montilla A.I., Mateu I., Pannell J.R. 2006. Ovule discounting in an outcrossing, cryptically dioecious tree. Evolution 60: 2056-2063.

Yaltirik F. 1978. Türkiye'de Doğal Oleaceae Taksonlarýnýn Sistematik Revizyonu. Ýstanbul Üniversitesi, Orman Fakültesi Yayýnlarý, No: 2404/250, Ýstanbul.

Yilmaz M. 2005. Doğu kayýný (Fagus orientalis Lipsky.) tohumlarýnýn fizyolojisi üzerine araştýrmalar, Doktora Tezi, Ýstanbul Üniversitesi, Fen Bilimleri Enstitüsü, p. 170.

Yilmaz M. 2006. Çimlenme engelinin giderilmesinde nem denetimli çýplak katlama yöntemi. Istanbul University Journal of Faculty of Forestry, Serial B, 56: 135-145.

Yilmaz M. and Tonguç F. 2008. Determination of seed characteristics of Fraxinus ornus subsp. cilicica. Project Report: 107 O 624, The Scientific and Technological Council of Turkey, p. 32.

Yilmaz M. and Tonguç F. 2009. Fruit and seed size variability of Fraxinus ornus subsp. cilicica. IJNES, 3(3): 122-125. 